\title{
Avaliação da Cintilação Ionosférica através do Índice S4 em estações da Rede CIGALA.
}

\author{
Jéssica Saldanha Souza* \\ UNESP - Faculdade de Ciências e Tecnologia. \\ 19060-900, Presidente Prudente, SP \\ E-mail: jessicasaldanha.souza@gmail.com \\ Daniele Barroca Marra Alves \\ UNESP - Faculdade de Ciências e Tecnologia, Depto de Cartografia \\ 19060-900, Presidente Prudente, SP \\ E-mail: danibarroca@fct.unesp.br \\ Crislaine Menezes da Silva \\ UNESP - Faculdade de Ciências e Tecnologia, Pós Graduação em Matemática \\ 19060-900, Presidente Prudente, SP \\ E-mail: cris_caju@hotmail.com
}

\begin{abstract}
RESUMO
O sinal GNSS (Global Navigation Satellite System) sofre influência de diversas irregularidades presente na atmosfera, uma delas é a cintilação ionosférica. A ionosfera em si pode ser modelada matematicamente, mas a cintilação é de difícil modelagem. Tal irregularidade pode ser descrita como uma mudança rápida na fase e amplitude do sinal GNSS, causada por irregularidades na densidade dos elétrons que estão ao longo do caminho, desde o satélite até o receptor. A cintilação ionosférica pode causar a degradação do sinal, podendo enfraquecê-lo ou até mesmo causando a sua perca total ${ }^{[1]}{ }^{[2]}$. Os períodos em que há a maior ocorrência de cintilação são aproximadamente durante os meses de março, abril, setembro e outubro (equinócio) e os mínimos nos meses de solstício de inverno e verão ${ }^{[2]}$.

Um dos índices que mapeiam a intensidade da cintilação ionosférica é o índice S4, onde $I$ é a intensidade do sinal recebido pelo satélite como mostra a seguinte equação:

$$
S_{4}^{2}=\frac{\left\langle I^{2}>-<I\right\rangle^{2}}{<I\rangle^{2}}
$$

Quando atingi-se o índice S4 > 0,707, alguns modelos de receptores são considerados bloqueados pela cintilação, ou seja, perdem quase ou totalmente o rastreio do sinal transmitido pelo satélite ${ }^{[1]}$. O índice S4 é o mais utilizado para medir a intensidade da cintilação para a pseudodistância no posicionamento GNSS, que pode ser descrita como:
\end{abstract}

$$
P D_{r}^{s}=\rho_{r}^{s}+c\left(d t_{r}-d t^{s}\right)+I_{s}^{r}+T_{s}^{s}+d m_{r}^{s}+V_{P D r}^{s}
$$

Onde $\rho_{\tilde{r}}^{s}$ é a distância geométrica entre o satélite, no instante de transmissão do sinal e o receptor, no instante de recepção do sinal; c - velocidade da luz no vácuo; $d t_{r} e d t^{s}$ são erros dos relógios do receptor e do satélite respectivamente; $I_{s}^{r}$ e $T_{s}^{r}$ são efeitos causados pela ionosfera e troposfera respectivamente; $d m_{r}^{s}$ é o efeito causado pelo multicaminho no código; $V_{P D}{ }^{s}$ é o erro da pseudodistância devido aos efeitos sistemáticos não modelados e aleatórios ${ }^{[2]}$.

A fim de avaliar os efeitos da cintilação no posicionamento foi desenvolvido no Brasil o projeto CIGALA (Concept for Ionospheric Scintillation Mitigation for Professional GNSS in Latin America) (http://cigala.galileoic.org/), onde foram instaladas oito estações em diferentes regiões do Brasil. Nesse artigo, foi utilizado o banco de dados do CIGALA, com a intenção de avaliar os índices S4 no ano de 2013, devido ao pico de atividade solar que teve inicio no final 
de 2013. As análises de 2013 serão em relação ao ano 2012, com o intuito de avaliar se ocorreu um aumento da cintilação neste período.

A estação escolhida para a avaliação do índice S4 foi a estação PRU2 que está instalada em Presidente Prudente - SP. Os meses escolhidos foram de março e outubro considerado um período de forte cintilação e junho considerado de baixa cintilação. A Figura 1 mostra graficamente como a cintilação se comporta nos meses escolhidos.
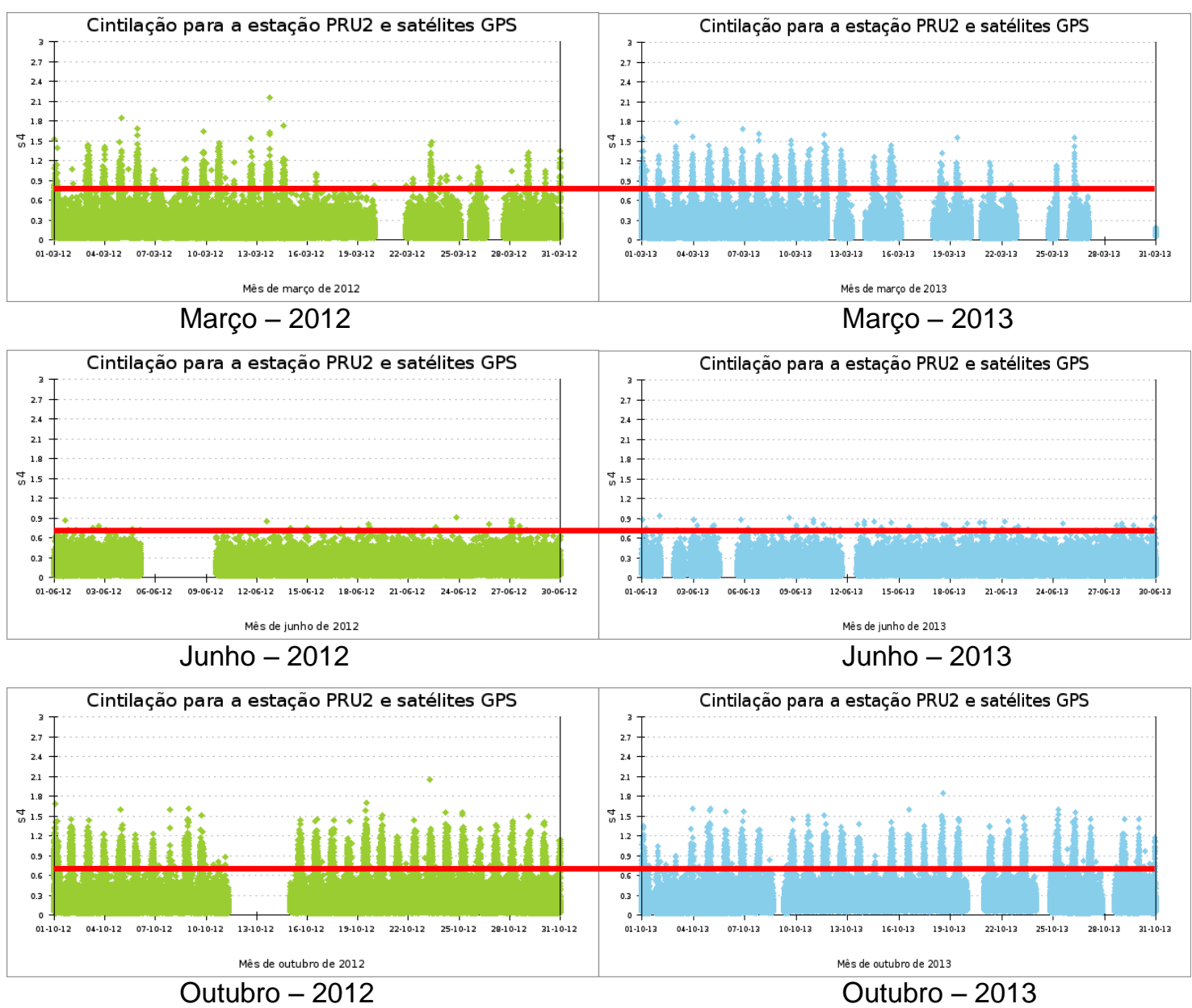

Figura 1 - Índices S4 para a estação PRU2

Como pode ser visto na Figura1 o índice S4 não obteve grandes diferenças do ano de 2012 para o ano de 2013, mostrando que o aumento da atividade solar esperado para a época não foi muito significativo, pois em 2013 deveria ter ocorrido picos maiores de cintilação e consequentemente um aumento do índice S4 muito mais acentuado do que ocorreu em 2012. É possível visualizar como o índice S4 obtém valores muito diferentes para junho e outubro, junho permanece com índices praticamente constantes e outubro atinge picos de cintilação diários com S4 >0,7 mostrando como a cintilação se mantém forte neste mês de outubro.

Palavras-chave: GNSS, Cintilação Ionosférica, índice S4.

\section{Referências}

[1] Conker, R. S., El-Arini, M. B. Hegarty, C. J., Hsiao, T. "Modeling the Effects of Ionospheric Scintillation on GPS/Satellite-Based Augmentation System Availability", Radio Science, Vol. 38. 2003.

[2] Monico, J. F. G. Posicionamento pelo GNSS: Fundamentos, Definição e Aplicação. 2 ed. São Paulo: Editora UNESP, 2008. 476p. 